\begin{tabular}{l|l|l} 
Jurnal Eksplorasi Akuntansi & ISSN : 2656-3649 (Online) \\
Vol. 2, No 1, Seri D, Februari 2020, Hal 2445-2465 & http://jea.ppj.unp.ac.id/index.php/jea/issue/view/20
\end{tabular}

\title{
PENGARUH SIKAP, PERSONAL COST OF REPORTING, DAN TINGKAT KESERIUSAN KECURANGAN TERHADAP INTENTION WHISTLEBLOWING PADA PEMERINTAH DAERAH
}

\author{
Hutriyal Alwi ${ }^{1}$, Nayang Helmayunita ${ }^{2}$ \\ ${ }^{1}$ Alumni Jurusan Akuntansi Fakultas Ekonomi, Universitas Negeri Padang \\ ${ }^{2}$ Jurusan Akuntansi Fakultas Ekonomi, Universitas Negeri Padang \\ *Korespondensi: mailto:hutriyalalwi@gmail.com
}

\begin{abstract}
This study aims to determine: the extent of the influence of attitude variables, the personal cost of reporting on fraud disclosure decisions or whistleblowing intention. The sample selection in this study uses a purposive sampling method in which the respondents are the ASN working in the Local Government Organizations (OPD) in Padang Pariaman. Respondents consisted of 104 people, who served at the head of the finance department, treasurer of the expenditure department, treasurer of the procurement of goods, as well as staff in the financial and accounting departments. Data collection techniques used in this study were using a questionnaire. Questionnaires that have been collected and filled out in full will be processed by data. From the results of data processing, it can be seen that the attitude variable has no effect on whistleblowing intention with a count of $1.477<t$ table 1.983, it can be said that the first hypothesis was rejected. While the results of the personal cost of reporting testing are also known to affect whistleblowing intention with a count of 6.407> 1.983 tables. But the hypothesis was rejected due to a positive effect. For the Level Intention of Fraud variable, it is known that it has a significant positive effect with count 2,280> t table 1,983. So that it can be said that the third hypothesis is accepted.
\end{abstract}

Keywords: Attitude, Personal Cost Of Reporting, Whistleblowing System, Level Intention Of Fraud, Local Government Organizations (OPD)

How to Cite (APA $6^{\text {th }}$ style):

Alwi, Hutriyal \& Helmayunita, Nayang. (2020). Pengaruh Sikap, Personal Cost of Reporting, Dan Tingkat Keseriusan Kecurangan Terhadap Intention Whistleblowing Pada Pemerintah Daerah. Jurnal Eksplorasi Akuntansi, 2(1), Seri D, 2445-2465.

\section{PENDAHULUAN}

Bentuk kecurangan yang paling sering terjadi pada penyelenggaraan pemerintah daerah adalah korupsi atau penyelewengan atas jabatan yang telah di amanahkan. Korupsi adalah suatu tingkah laku yang menyimpang dari tugas-tugas resmi jabatannya dalam negara, dimana untuk memperoleh keuntungan status atau uang yang menyangkut diri pribadi atau perorangan, 
keluarga dekat, kelompok sendiri atau dengan melangggar aturan pelaksanaan yang menyangkut tingkah laku pribadi (Robert Klitgaard).

Menurut data dari ICW (Indonesia Coruption Watch) selama tahun 2004 sampai dengan 2018 terdapat 104 Kepala Daerah tersandung korupsi yang ditangani oleh KPK, jumlah yang paling tinggi justru terjadi pada Tahun 2018 yakni sebanyak 29 kasus (Kepala Daerah) disusul 2014 sebanyak 14 kasus (Kepala Daerah). Penyebab semakin menjamurnya korupsi di daerah adalah lemahnya pengawasan Pemerintah Pusat pada Pemerintah Daerah serta minimnya system checkand balances mengakibatkan penyalahgunaan wewenang kerap dilakukan Pejabat Daerah.

Penyimpangan atau fraud merupakan kesalahan penyajian dari fakta material yang dibuat oleh salah satu pihak ke pihak lain dengan niatan untuk menipu dan menyebabkan pihak lain yang mengandalkan fakta tersebut mengalami kerugian (James Hall, 2011). Penyelenggaraan Pemerintah Daerah dengan kasus penyimpang/fraud tertinggi tentunya akan berdampak kepada pelayanan kepada masyarakat dan perkembangan daerah itu sendiri. System Whistleblowing merupakan salah satu solusi yang efektif untuk mengungkapkan kecurangan yang terjadi.

Sedangkan Whistleblower adalah seseorang (pegawai/mantan pegawai dalam organisasi) yang melakukan tindakan pengungkapan/memberitahukan kepada publik atau kepada manajemen puncak tentang adanya dugaan tindakan illegal/tidak etis (Susmanschi, 2012). Whistleblowing terbagi dua yaitu Whistleblowing internal dan eksternal.

Negara Kesatuan Republik Indonesia telah menetapkan aturan mengenai Whistleblowing, aturan tersebut tertuang pada Undang-Undang Nomor 13 Tahun 2006 tentang Perlindungan Saksi dan Korban serta Surat Edaran Mahkamah Agung Nomor 4 Tahun 2011 tentang Perlakuan terhadap Pelapor Tindak Pidana dan Saksi Pelaku yang Bekerja Sama. Bentuk kasus Whistleblowing yang pernah terjadi di Indonesia adalah terpidana korupsi pengamanan pemilihan Gubernur Jawa Barat dan perkara PT Salmah Arowana Lestari (SAL) oleh Susno Duadji. Susno Duadji sempat melawan Institusinya sendiri karena mengungkapkan modus makelar proyek di tubuh Polri hingga akhirnya ditetapkan sebagai Whistleblower,Susno Duadji juga menerima Whistleblower Award dari Komunitas Pengusaha Anti Suap pada 21 April 2010 (detiknews, Rabu 24 April 2013).

Aturan whistleblowing system sudah diterapkan oleh Pemerintah Daerah Kabupaten Padang Pariaman sejak Tahun 2018. Aturan tersebut tertuang ke dalam Peraturan Bupati Padang Pariaman Nomor 16 Tahun 2018 tentang Pedoman Penyampaian Pengaduan oleh Aparatur Sipil Negara Dan/Atau Pejabat Lain (Whistleblower System) di lingkungan Pemerintah Kabupaten Padang Pariaman.

Seseorang melakukan tindakan Whistleblowing tentu saja dilandasi oleh niat atau keinginan dalam hati untuk mengungkapkan perbuatan seseorang/kelompok yang melangar aturan. Tanpa adanya niat tentu sikap Whistleblowing tidak akan dapat dilakukan. Pada Theory Planned Of Behavior (Teori Perilaku Terencana) dijelaskan bahwa perilaku untuk melakukan sesuatu didasari oleh niat untuk melakukan perilaku pada waktu dan tempat tertentu. Untuk itu agar Whistleblowing dapat bermunculan pada sektor Publik, perlu dilakukan terlebih dahulu penyebab apa saja yang menjadi faktor-faktor seorang Aparatur Sipil Negara memiliki niat melakukan Whistleblowing. Sikap merupakan kepercayaan positif atau negatif untuk menampilkan suatu perilaku tertentu. Sikap ditentukan oleh kepercayaan-kepercayaan individu mengenai konsekuensi dari penampilan suatu perilaku (Behavioral Beliefs), ditimbang berdasarkan hasil evaluasi terhadap konsekuensinya (Outcome Evalution).

Ketika individu menentukan sikap untuk melakukan tindakan intention whistleblowing, maka individu tersebut menilai bahwa sikap yang dilakukannya memiliki konsekuensi positif 
terhadap lingkungannya. Hal ini sejalan dengan Teori of Planned Behavior, sikap merupakan salah satu variabel yang mempengaruhi minat perilaku seseorang. Banyak faktor yang mempengaruhi seseorang untuk melakukan whistleblowing, namun sikap individu sendiri menjadi sangat penting untuk menjadikan dirinya seorang whistleblower atau tidaknya.

Selanjutnya yang mempengaruhi niat seseorang untuk melakukan Whistleblowing adalah Personal Cost Of Reporting. Personal Cost Of Reporting merupakan pandangan pegawai terhadap resiko pembalasan/balas dendam maupun sanksi dari anggota organisasi, yang dapat mengurangi niat pegawai untuk melaporkan wrongdoing/kecurangan (Schultz et al., 1993 dalam Bagustianto). Aparatur Sipil Negara (ASN) yang menyaksikan kecurangan dilingkungan kerjanya tidak berarti ia akan melaporkannya.

Menurut National Business Ethics Survey (2007) pegawai biasanya takut akan adanya tindak pembalasan dari organisasi, atasan maupun rekan-rekan kerja. Jadi, Personal Cost Of Reporting sangat berpengaruh besar terhadap Intention Whistleblowing. Ketika semakin tinggi tingkat persepsi Personal Cost Of Reporting seseorang, maka semakin rendah pula tindakan orang tersebut untuk melakukan Whistleblowing dan sebaliknya. Faktor terakhir dalam penelitian ini yang mempengaruhi Intention Whistleblowing adalah Tingkat Keseriusan Kecurangan. Anggota organisasi yang mengamati adanya dugaan wrongdoing/kecurangan akan lebih mungkin untuk melakukan whistleblowing jika wrongdoing/kecurangan tersebut serius (Miceli dan Near, 1985). Ketika seorang pegawai mengetahui kecurangan yang terjadi dengan tingkat keseriusan kecurangan rendah, maka intention whistleblowing juga rendah. Namun ketika pegawai mengetahui terjadi tingkat keseriusan kecurangan yang tinggi, maka intention whistleblowing juga akan semakin tinggi terjadi.

Berbagai penelitian tentang Whistleblowing telah banyak dilakukan oleh peneliti terdahulu. Namun masih perlu dilakukan pengujian ulang terhadap penelitian tersebut, dikarenakan masih memiliki hasil penelitian yang berbeda-beda. Seperti pada penelitian Siti Aliyah (2015) yang menyatakan bahwa sikap tidak berpengaruh signifikan terhadap minat pegawai dalam melakukan tindakan whistleblowing sedangkan menurut penelitian Winardi (2013), Riri Permata Sari (2018) dan Rizki Bagustianto (2015) menunjukkan bahwa sikap memiliki pengaruh yang signifikan terhadap minat pegawai melakukan whistleblowing.

Karena masih banyaknya perbedaan hasil penelitian oleh peneliti terdahulu serta peneliti juga ingin mengetahui bagaimana pengaruh sikap, personal cost of reporting dan tingkat keseriusan kecurangan terhadap minat Pegawai Negeri Sipil melakukan intention whistleblowing di Pemerintah Daerah Kabupaten Padang maka penulis tertarik kembali untuk melakukan penelitian tentang intention whistleblowing pada Pemerintah Daerah dengan lingkungan yang berbeda. Adanya hasil penelitian yang berbeda-beda, menunjukkan bahwa masih terjadi kesenjangan pada penelitian tentang intention whistleblowing. Penelitian ini lebih menfokuskan responden kepada Aparatur Sipil Negara yang bekerja pada Bagian Keuangan Organisasi Perangkat Daerah (OPD) Kabupaten Padang Pariaman. Bagian Keuangan merupakan pengguna paling potensial dari sistem whistleblowing karena pegawai pada bagian keuangan secara aktif terlibat dalam kegiatan operasional dan teknis dari instansi tersebut (Magnus dan Viswesvaran, 2005).

Tujuan dari penelitian ini adalah untuk membuktikan dan memperoleh bukti empiris sejauhmana pengaruh sikap terhadap keputusan pengungkapan kecurangan, sejauh mana pengaruh personal cost of reporting terhadap keputusan pengungkapan kecurangan dan sejauhmana pengaruh tingkat keseriusan kecurangan terhadap keputusan pengungkapan kecurangan. Maka dari itu peneliti tertarik untuk mengambil judul penelitian yakni: "Pengaruh 
Sikap, Personal Cost Of Reporting dan Tingkat Keseriusan Kecurangan terhadap Intention Whistleblowing"

\section{REVIEW LITERATUR DAN PENGEMBANGAN HIPOTESIS Teori Planned Behaviour}

Teori ini merupakan teori psikologi yang berusaha menjelaskan hubungan antara sikap dengan perilaku. Teori ini membuktikan bahwa niat (intention) lebih akurat dalam memprediksi perilaku aktual. Oleh karena itu, berdasarkan TPB tersebut niat dijadikan sebagai faktor utama dalam memprediksi tindakan whistleblowing seseorang. Menurut Ajzen (1991) Teori Perilaku Terencana (theory of planned behaviour) mendefinisikan sikap sebagai jumlah dari perasaan (afeksi) yang dirasakan sesseorang untuk mendukung atau menolak suatu objek yang dihadapi dan perasaan yang dirasakan tersebut diukur dengan skala evaluative seperti baik atau buruk, setuju atau tidak setuju dan penting atau tidak penting.

Terdapat tiga tipe keyakinan dasar yang digunakan oleh Ajzen (1991) untuk mengukur intention whistleblowing seseorang. Keyakinan perilaku (behavior beliefs), keyakinan normatif (normative beliefs) dan keyakinan kontrol (control beliefs). Berdasarkan konsep niat terdiri dari tiga determinan independen. Determinan pertama yaitu sikap terhadap perilaku (attitude towards behaviours), sikap terhadap perilaku merupakan tingkatan dimana seseorang mengevaluasi atau menilai apakah perilaku tersebut baik dilakukan atau tidak.

\section{Whistleblowing}

Menurut Bouville (2007) Whistleblowing merupakan tindakan dari seorang pegawai (atau mantan pegawai) untuk mengungkapkan apa yang ia percaya sebagai perilaku ilegal atau tidak etis kepada manajemen yang lebih tinggi/manajemen puncak (internal whistleblowing) atau kepada otoritas/pihak yang berwenang diluar organisasi maupun kepada publik (eksternal whistleblowing). Whistleblowing adalah pengungkapan tindakan kecurangan atau perbuatan yang melawan hukum, kesalahan prosedur, korupsi, penyalahgunaan wewenang dan perbuatan tidak etis yang dapat merugikan berbagai pihak yang berkepentingan (KNKG, 2008). Whistleblowing dapat terjadi didalam maupun diluar sektor perusahaan atau sektor pemerintahan. Menurut Elias (2008) terdapat dua jenis pelaporan pelanggaran yaitu whistleblowing eksternal dan whistleblowing internal.

\section{Sikap}

Menurut (Gerungan, 2004:160) Sikap merupakan suatu reaksi pandangan atau perasaan seorang individu terhadap suatu objek. Walaupun objeknya sama, namun tidak semua individu mempunyai sikap yang sama, hal itu dapat dipengaruhi oleh keadaan individu, pengalaman, informasi dan kebutuhan masing-masing individu berbeda (Cheisviyanny \& Arza, 2019). Sikap seseorang terhadap objek akan membentuk perilaku individu terhadap objek. Sikap terhadap perilaku menurut Davis et al (dalam Jogiyanto, 2007) didefenisikan sebagai perasaan positif atau negatif seseorang jika harus melakukan perilaku yang akan ditentukan. Menurut Ajzen (1991) mendefinisikan sikap sebagai derajat individu untuk mengevaluasi dan menilai sesuatu yang menguntungkan atau tidak menguntungkan.

Sikap seorang karyawan terhadap whistleblowing akan mempengaruhi minat karyawan tersebut untuk melakukan whistleblowing. Menurut Park dan Blenkinsopp (2009), sikap terhadap whistleblowing mengenai sejauh mana individu memiliki evaluasi menguntungkan atau tidak 
menguntungkan dari whistleblowing akan jumlah keyakinan yang dimiliki karyawan tentang konsekuensi dari whistleblowing dan evaluasi subjektif terhadap konsekuensi tersebut.

\section{Personal Cost Of Reporting}

Personal Cost Of Reporting merupakan pandangan pegawai terhadap resiko pembalasan/balas dendam atau sanksi dari anggota organisasi, yang dapat mengurangi minat pegawai untuk melakukan whistleblowing (Schultz et al, 1993 dalam Bagustianto, 2014). Personal Cost Of Reporting dapat berupa tindakan seperti melemahkan proses pengaduan, pengucilan dan diskriminasi terhadap whistleblower. Menurut Curts (2006) ancaman pembalasan yang mungkin akan diterima oleh seorang pegawai jika mengungkapkan kecurangan yang ada di organisasi dapat berupa mutasi ke bagian lain yang tidak sesuai dengan kompetensi yang dimiliki dan mendapatkan penilaian kinerja yang tidak adil.

Personal Cost merupakan salah satu alasan utama yang menyebabkan seseorang tidak ingin menjadi whistleblower karena mereka meyakini akan mengalami retalisasi. Retaliasi atau tindakan balas dendam adalah sebuah perilaku yang ditujukan untuk mengembalikan tindakan yang pernah dilakukan seseorang. Oleh karena itu persepsi personal cost sangat mempengaruhi niat seseorang untuk melaporkan kecurangan. Semakin besar persepsi personal cost seseorang maka akan semakin mengurangi niat seseorang untuk melakukan tindakan whistleblowing.

\section{Tingkat Keseriusan Kecurangan}

Tingkat keseriusan kecurangan menjadi faktor penting dalam munculnya tindakan whistleblowing. Menurut Curtls (2006) dalam winardi (2013) tingkat keseriusan kecurangandapat dilihat dari seberapa besar impact yang disebabkan oleh kecurangan tersebut. Menurut (Miceli dan Near, 1985) anggota organisasi yang mengamati adanya dugaan kecurangan, apalagi kecurangan tersebut bersifat serius, maka orang tersebut akan lebih mungkin untuk melakukan whistleblowing. Jadi, ketika wrongdoing terjadi dengan tingkat keseriusan yang tinggi dan dapat merugikan nilai keuangan yang besar bagi perusahaan. Maka keinginan untuk melakukan whistleblowing juga akan semakin besar dengan harapan wrongdoing dapat dihentikan.

Dapat ditarik kesimpulan, tingkat keseriusan kecurangan akan menentukan apakah perlu dilakukan whistleblowing atau tidaknya. Ketika kecurangan yang terjadi sudah sangat merugikan organisasi maka tindakan whistleblowing akan dilakukan untuk menyelamatkan kerugian dari kecurangan tersebut. Namun, jika kecurangan masih dalam tahap dapat ditolerir maka whistleblowing akan mungkin tidak terjadi atau pelaporan kecurangan masih dalam skala rendah.

\section{Penelitian Terdahulu}

Resi Marliza, 2018, Pengaruh Personal Cost of Reporting, Komitmen Organisasi dan Tingkat Keseriusan Kecurangan Terhadap Niat Melakukan Whistleblowing. Hasil penelitian menemukan Komitmen Organisasi dan Tingkat Keseriusan Kecurangan berpengaruh signifikan positif terhadap niat melakukan whistleblowing, sedangkan personal cost of reporting tidak berpengaruh signifikan positif terhadap niat melakukan whistleblowing. Siti Aliyah, 2015, Analisis Faktor-Faktor yang Mempengaruhi Minat Pegawai dalam Melakukan Tindakan Whistleblowing. Hasil penelitian menemukan Sikap, Komitmen Organisasi, Tingkat Keseriusan Kecurangan dan Tanggung Jawab Personal tidak berpengaruh signifikan terhadap whistleblowing sedangkan Personal Cost berpengaruh negatif dan signifikan terhadap whistleblowing 
Riri Permata Sari, 2018, Faktor-Faktor yang Mempengaruhi Pegawai Negeri Sipil Untuk Melakukan Tindakan Whistleblowing. Hasil penelitian menemukan Sikap dan Personal Cost memiliki pengaruh yang signifikan terhadap whistleblowing, Komitmen Organisasi berpengaruh positif terhadap whistleblowing dan Tingkat Keseriusan Kecurangan berpengaruh terhadap whistleblowing. Rizki Bagustianto, 2014, Faktor-Faktor yang Mempengaruhi Minat PNS untuk Melakukan Tindakan Whistleblowing. Hasil penelitian ini menemukan bahwa Faktor Sikap terhadap whistleblowing, Komitmen Organisasi dan Tingkat Keseriusan Kecurangan memiliki pengaruh yang signifikan terhadap minat melakukan whistleblowing.

\section{Pengembangan Hipotesis}

\section{Sikap}

Sikap terhadap whistleblowing merupakan keyakinan bahwa tindakan yang dilakukan memiliki dampak positif, seperti melindungi organisasi, memberantas korupsi, memunculkan efek jera, menumbuhkan budaya anti korupsi serta ingin mendapatkan reputasi dan penghargaan. Selanjutnya keyakinan akan sikap tersebut dievaluasi oleh sistem penilaian individu dan memunculkan tindakan emosional. Winardi (2013) juga menemukan bahwa sikap memiliki pengaruh positif terhadap whistleblowing internal. Berdasarkan penjelasan diatas, maka dapat ditarik hipotesis sebagai berikut.

$\mathrm{H}_{1}$ : Sikap terhadap whistleblowing berpengaruh positif terhadap niat melakukan whistleblowing.

\section{Personal Cost Of Reporting}

Menurut (Zhuang, 2003:21) personal cost yang paling dipertimbangkan adalah pembalasan dari orang-orang dalam organisasi yang mengungkapkan pelaporan kecurangan karena dianggap tidak etis jika kecurangan tersebut dilakukan oleh atas/manager karena dianggap menentang atasannya. Personal Cost Of Reporting sangat memiliki pengaruh terhadap niat melakukan whistleblowing. Penelitian Kusuma dan Andayani (2017) dan Taufik Nugraha (2017) menyatakan bahwa personal cost berpengaruh positif terhadap niat untuk melakukan whistleblowing. Jadi, Semakin rendah personal cost of reporting maka akan meningkat intensi whistleblowing seseorang dan sebaliknya. Maka dapat ditarik hipotesis sebagai berikut.

$\mathrm{H}_{2}$ : Personal Cost Of Reporting berpengaruh negatif terhadap niat melakukan whistleblowing.

\section{Tingkat Keseriusan Kecurangan}

Tingkat keseriusan kecurangan berbeda-beda menurut persepsi orang masing-masing, tergantung kepada penilaian dan asumsi tiap-tiap individu terhadap kecurangan tersebut. Keseriusan kecurangan dapat diukur terhadap dampak yang diterima oleh organisasi, motivasi pelaku dan etis atau tidak etisnya kecurangan tersebut. Seseorang cenderung akan melaporkan kecurangan ketika kecurangan tersebut menimbulkan kerugian yang signifikan bagi individu maupun kelompok. Orang tersebut mengganggap kecurangan tersebut akan mengakibatkan kerugian pada banyak orang dan patut untuk dilaporkan dibandingkan dengan kecurangan yang hanya memberikan dampak kepada pelaku kecurangan saja. Hasil dari penelitian Bagustianto dan Nurcholis (2013) serta Winardi (2013) dengan menggunakan konsep materialitas sebagai pembeda tingkat keseriusan kecurangan, juga mengkonfirmasi akan adanya hubungan dengan teori perilaku prososial.

Hal ini sejalan dengan penelitian Fajri (2017) yang menyatakan bahwa tingkat keseriusan kecurangan berpengaruh terhadap niat untuk melakukan whistleblowing. Dan terdapat beberapa penelitian lain seperti Bagustianto dan Nurkholis (2015), Setyawati, Komala dan Ragil (2015, 
Raharjo (2015) yang menyatakan tingkat keseriusan kecurangan berpengaruh terhadap intention whistleblowing.

Jadi, dapat disimpulkan bahwa seseorang akan melaporkan kecurangan jika melihat dampak negatif yang akan terjadi pada lingkungan sekitarnya. Pelapor akan melakukan penghentian tindakan untuk meminimalisir kerugian yang diterima kelompok maupun individu itu sendiri. Maka dapat ditarik hipotesis sebagai berikut.

$\mathrm{H}_{3}$ : Tingkat keseriusan kecurangan berpengaruh positif terhadap niat melakukan whistleblowing.

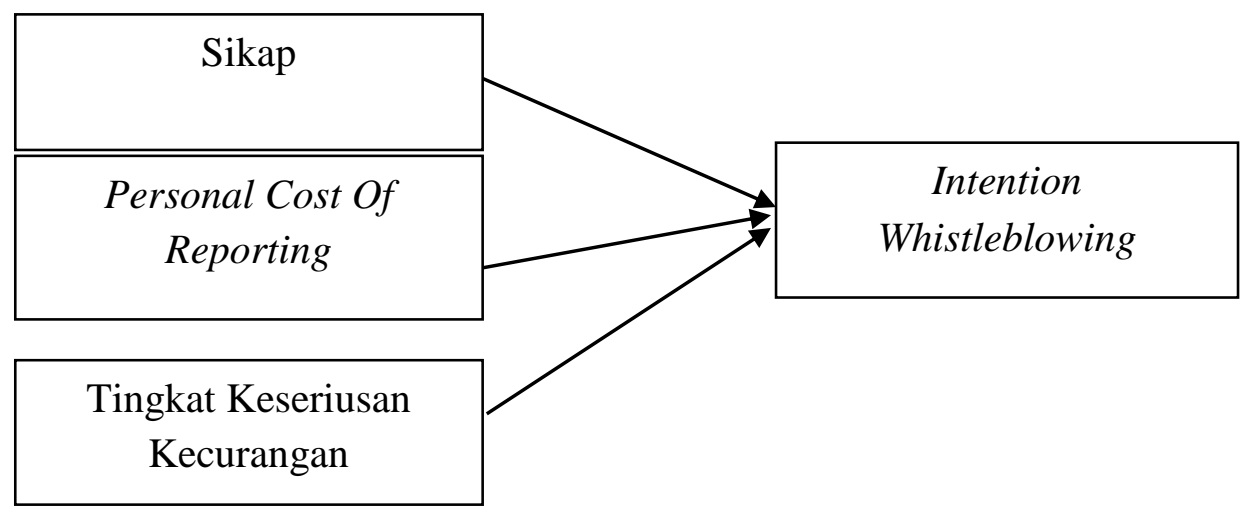

Gambar 1 Kerangka Konseptual

\section{METODE PENELITIAN}

Penelitian ini menggunakan metode penelitian kuantitatif yakni penelitian pada populasi atau sampel tertentu, adanya pengumpulan data, menggunakan instrument penelitian, analisis data bersifat kuantitatif atau statistik yang bertujuan untuk menguji hipotesis yang telah ditetapkan (Sugiyono, 2013:2).

\section{Populasi dan Sampel}

Populasi yang digunakan dalam penelitian ini adalah 26 Organisasi Perangkat Daerah (OPD) dengan berbagai tipe organisasi yang ada pada lingkungan Pemerintah Daerah Kabupaten Padang Pariaman.

\section{Sampel}

Sampel merupakan bagian dari jumlah yang dimiliki oleh populasi dan memiliki karakteristik yang sudah ditetapkan oleh peneliti (Sugiyono, 2013:80). Sampel pada penelitian ini berjumlah 104 Orang yang merupakan pegawai yang bekerja pada bagian keuangan Organisasi Perangkat Daerah (OPD) yakni Pejabat Penatausahaan Keuangan (PPK), Bendahara Pengeluaran, Bendahara Barang dan Staf keuangan. Pada penelitian ini penentuan sampel ditetapkan dengan teknik Purposive Sampling, yakni pengambilan sampel berdasarkan kriteria yang dipilih untuk memenuhi kebutuhan data penelitian.

Pengambilan sampel pada bagian keuangan dipilih oleh peneliti karena bagian tersebut secara aktif terlibat dalam kegiatan operasional dan teknis dari Instansi Pemerintahan. Bagian keuangan sangat mengetahui secara rinci kegiatan Organisasi Perangkat Daerah, sehingga ketika adanya indikasi kecurangan maupun kesalahan prosedur yang terjadi, Pegawai yang bekerja pada bagian keuangan dapat secara potensial menjadi whistleblower. 


\section{Jenis, Sumber dan Teknik Pengumpulan Data}

Pada penelitian ini jenis data yang digunakan adalah data subyek (self-report data) yang berupa sikap, pengalaman, opini, karakter seseorang yang menjadi subyek penelitian (responden). Data yang digunakan pada penelitian ini adalah data primer. Data primer adalah data yang diperoleh peneliti secara langsung dari responden, atas data pribadi responden, data pandangan terhadap whistleblowing, pandangan tentang sikap, personal cost of reporting dan tingkat keseriusan kecurangan yang mempengaruhi niat seseorang untuk melakukan tindakan whistleblowing.

Teknik yang digunakan oleh peneliti dalam pengumpulan data adalah kuesioner. Kuesioner disebarkan kepada sampel yang telah dipilih oleh peneliti yang diantarkan langsung ke alamat Organisasi Perangkat Daerah (OPD) di lingkungan Pemerintah Daerah Kabupaten Padang Pariaman.

\section{Instrumen Penelitian}

Penelitian ini menggunakan kuesioner untuk membantu penulis memperoleh hasil atas perumusan masalah. Variabel yang diteliti menggunakan pengukuran skala likert 1 sampai dengan 5. Untuk variabel sikap instrument penelitian yang digunakan diadopsi dari penelitian sebelumnya yang dilakukan oleh Maulana ilham (2016). Sedangkan untuk instrument dari variabel personal cost of reporting diadopsi dari penelitian Curtis (2016) dan untuk variabel tingkat keseriusan kecurangan juga diadopsi dari penelitian sebelumnya Curtis (2006). Dan untuk variabel dependen dalam penelitian ini yakni intention whistleblowing diadopsi dari penelitian sebelumnya yang dilakukan oleh Ajzen (2002), Park \& Bleinkinsop (2009) serta Winardi dan Bagustianto (2014).

\section{Metode Analisis Data}

Berdasarkan dari data kuesioner yang telah disebar serta dikumpulkan, maka akan dilakukan analisis data untuk mendapatkan hasil dari penelitian. Teknik analisis data dalam penelitian ini akan menggunakan regresi berganda.

\section{Uji Model}

\section{Koefisien Regresi Berganda}

Model regresi berganda yang digunakan dalam penelitian ini dengan persamaan sebagai berikut :

$$
\begin{aligned}
& \mathrm{Y}=5,809+0,436 \mathrm{X}_{1}+0,548 \mathrm{X}_{2}+0,240 \mathrm{X}_{3} \\
& \text { Dimana: } \\
& \mathrm{Y} \quad=\text { Intention Whistleblowing } \\
& \mathrm{X} 1 \quad=\text { Sikap } \\
& \mathrm{X} 2 \quad=\text { Personal Cost Of Reporting } \\
& \mathrm{X} 3 \quad=\text { Tingkat Keseriusan Kecurangan }
\end{aligned}
$$

\section{Uji Normalitas}

Uji normalitas data yang digunakan dalam penelitian ini adalah metode kolmograv smirnov dengan kriteria nilai signifikan atau probabilitas $<0,05$ maka distribusi data adalah tidak normal dan nilai signifikansi atau probabilitas $>0,05$ maka distribusi data adalah normal. 


\section{Uji Multikolinearitas}

Uji multikolinearitas dilakukan untuk mengetahui apakah ada gejala korelasi antar variabel independen. Uji dilakukan dengan melihat data pada variabel bebas yaitu : melihat angka collinearity statistic yang ditujukan oleh nilai variance inflation factor (VIF). Jika VIF > 10 maka variabel bebas yang ada memiliki masalah multikolinearitas. Dengan melihat nilai tolerance pada output penilaian multikolinearitas yang tidak menunjukkan nilai yang lebih besar dari 0,1 akan memberikan kenyataan bahwa tidak terjadi masalah multikolinearitas.

\section{Uji Heterokedastisitas}

Uji ini untuk melihat apakah model regresi terjadi ketidaksamaan variabel dari residual satu pengamatan ke pengamatan lain dengan menggunakan uji gletser. Jika sig > 0,05 maka tidak terdapat gejala heterokedastisitas.

\section{HASIL DAN PEMBAHASAN \\ Gambaran Umum Objek Penelitian}

Sebagimana yang telah dijelaskan pada bagian pendahuluan, penelitian ini bertujuan untuk membuktikan secara empiris pengaruh dari sikap, personal cost of reporting, serta tingkat keseriusan kecurangan terhadap intention whistleblowing. Jumlah populasi dalam penelitian ini adalah sebanyak 104 orang Aparatur Sipil Negara di lingkungan Pemerintah Daerah Kabupaten Padang Pariaman dari seluruh Organisasi Perangkat Daerah (OPD) yang ada.

Peneliti melakukan pembagian kuesioner secara langsung turun kelapangan dan mendatangi setiap OPD yang ada di Kabupaten Padang Pariaman, kemudian kuesioner akan diambil kembali paling cepat dua hari kerja paling lambat 2 minggu setelah kuesioner disebar. Hasil dari penyebaran dan pengembalian kuesioner dapat dilihat pada tabel 1 berikut :

Tabel 1

Tingkat pengembalian Kuesioner

\begin{tabular}{ll}
\hline \multicolumn{1}{c}{ Keterangan } & $\begin{array}{l}\text { Jumlah } \\
\text { Kuesioner }\end{array}$ \\
\hline Jumlah kuesioner yang disebar & 104 \\
\hline Jumlah kuesioner yang kembali & 104 \\
\hline $\begin{array}{l}\text { Jumlah kuesioner yang lengkap diisi dan } \\
\text { dapat diolah }\end{array}$ & 104 \\
\hline
\end{tabular}

\begin{tabular}{ll}
\hline Respon Rate & $100 \%$ \\
\hline
\end{tabular}

Sumber : Data primer yang diolah, Tahun 2019

\section{Demografi Responden}

Berdasarkan hasil kuesioner yang telah diisi oleh responden, diketahui karakteristik responden disajikan secara umum menurut kategori : jenis kelamin, usia, tingkat pendidikan, jabatan serta pangkat atau golongan. Karakteristik Responden Berdasarkan Jenis Kelamin Adapun untuk proporsi responden berdasarkan jenis kelamin dapat dilihat pada tabel 2 berikut ini : 
Tabel 2

Karakteristik Responden Berdasarkan Jenis Kelamin

No Jenis Kelamin Jumlah Persentase

\begin{tabular}{cccc}
\hline 1 & Laki-Laki & 43 & $41,35 \%$ \\
\hline 2 & Perempuan & 61 & $58,65 \%$ \\
& & & \\
\hline & Jumlah & 104 & $100 \%$
\end{tabular}

Sumber : Data primer yang diolah, Tahun 2019

\section{Karakteristik Responden Berdasarkan Usia}

Berdasarkan kuesioner yang telah diisi secara lengkap dan dikumpulkan maka dapat diketahui kategori usia dari masing-masing responden. Adapun kategori usia responden disajikan pada tabel 3 sebagai berikut :

Tabel 3

Karakteristik Responden Berdasarkan Usia

\begin{tabular}{cccc}
\hline No & Usia Responden & Jumlah & Persentase \\
\hline 1 & $<30$ Tahun & 19 & $18,27 \%$ \\
\hline 2 & $30-40$ Tahun & 62 & $59,62 \%$ \\
\hline 3 & $41-50$ Tahun & 18 & $17,31 \%$ \\
\hline 4 & $>50$ Tahun & 5 & $4,81 \%$ \\
\hline & JUMLAH & $\mathbf{1 0 4}$ & $\mathbf{1 0 0 \%}$ \\
\hline
\end{tabular}

\section{Statistik Deskriptif}

Dalam penelitian ini menggunakan tiga variabel independen yakni sikap, personal cost of reporting serta tingkat keseriusan kecurangan. Sedangkan variabel dependen dalam penelitian ini adalah intention whistleblowing. Gambaran dari masing-masing variabel tersebut dapat lihat pada tabel 4 sebagai berikut :

Tabel 4

Statistik Deskriptif Descriptive Statistics

N Minimum Maximum Mean Std. Deviation

\begin{tabular}{|c|c|c|c|c|}
\hline Sikap & 104 & 9 & 1512.80 & 1.194 \\
\hline Personal Cost Of Reporting & 104 & 25 & 4835.27 & 4.291 \\
\hline Tingkat Keseriusan Kecurangan & 104 & 14 & 3022.48 & 3.531 \\
\hline Intention Whistleblowing & 104 & 24 & 4636.10 & 4.491 \\
\hline Valid N (listwise) & 104 & & & \\
\hline
\end{tabular}


Dari data tabel 4 diatas dapat diperoleh bahwa variabel sikap (X1) memiliki nilai minimum sebesar 9 (sembilan) dan nilai maximum sebesar 15 (lima belas). Nilai mean dari variabel sikap adalah 12,80, dengan standar deviasi sebesar 1,194. Selanjutnya untuk variabel personal cost of reporting (X2), memiliki nilai minimum 25 (dua puluh lima), sedangkan nilai maximum untuk variabel personal cost of resporting adalah sebesar 48 (empat puluh delapan). Nilai tengah atau mean untuk variabel personal cost of reporting adalah sebesar 35,27 dengan standar deviasi sebesar 4,291.

\section{Uji Validitas}

Uji validitas digunakan untuk megetahui apakah kuesioner yang telah dibagikan valid. Sebelum memulai uji validitas, peneliti harus mengetahui dasar pengambilan keputusan mengenai uji validitas yakni jika $r_{\text {hitung }}>r_{\text {tabel }}$ maka dapat dikatakan bahwa kuesioner dinyatakan valid. Penelitian ini menggunakan sampel sebanyak 104 orang maka, rtabel $\mathrm{N}=104=0,1606$.

Secara keseluruhan pernyataan yang valid harus memiliki nilai $r_{h i t u n g}>r_{\text {tabel, }}$ maka dapat dikatakan bahwa seluruh pernyataan variabel independen sikap $\left(\mathrm{X}_{1}\right)$ adalah valid. Selanjutnya untuk keseluruhan item pernyataan yang ada pada variabel independen $\mathrm{X}_{2}$ yakni Personal Cost Of Reporting dinyatakan valid. Untuk variabel independen $\mathrm{X}_{3}$ dalam penelitian ini Tingkat keseriusan kecurangan juga dikatakan seluruh item pernyataan valid dan variabel dependen Intention Whistleblowing seluruh pernyataan dalam kuesioner valid. Sehingga dapat digunakan untuk pengujian lanjutan dalam analisis regresi berganda.

\section{Uji Reliabilitas (Reliability Analysis)}

Uji Reliabilitas digunakan untuk mengukur tingkat konsistensi antara hasil pengamatan dengan instrumen atau alat ukur yang digunakan pada waktu yang berbeda. Teknik yang digunakan untuk mengukur reliabilitas penelitian yakni dengan menggunakan nilai koefisien dari cronbach alpha. Untuk uji reliabilitas dalam penelitian ini dapat dilihat pada tabel 5 sebagai berikut :

Tabel 5

Hasil Uji Reliabilitas

\begin{tabular}{lccc}
\hline \multicolumn{1}{c}{ Variabel Penelitian } & $\begin{array}{c}\text { Nilai } \\
\text { Cronbac'hs } \\
\text { Alpha }\end{array}$ & $\mathbf{r}_{\text {tabel }}$ & Keterangan \\
\hline Sikap (X1) & 0,494 & 0,1606 & Reliabel \\
\hline Personal Cost Of Reporting (X2) & 0,426 & 0,1606 & Reliabel \\
\hline Tingkat Keseriusan Kecurangan (X3) & 0,657 & 0,1606 & Reliabel \\
\hline Intention Whistleblowing $(Y)$ & 0,483 & 0,1606 & Reliabel \\
\hline
\end{tabular}

Dari data pada tabel 5 dapat diambil kesimpulan bahwa secara keseluruhan variabel dapat dikatakan reliabel, sehingga hasil dari pernyataan dari masing-masing responden konsisten. Untuk variabel sikap memiliki nilai cronbac'hs aplha sebesar 0,494 dengan kategori tidak buruk.

\section{Uji Normalitas}

Uji normalitas dilakukan untuk menguji apakah dalam sebuah penelitian dengan model regresi, variabel dependen dan independen terdistribusi secara normal atau tidak. Dalam penelitian ini uji 
normalitas dilakukan dengan menggunakan metode one sample kolmogrov-smirnov. Uji normalitas dalam penelitian ini diperoleh melalui Software Progam SPSS versi 23. Adapun dalam penelitian ini uji normalitas dapat dilihat pada tabel 6 berikut ini:

Tabel 6

Uji Normalitas One Sample Kolomgrov - Smirnov

\begin{tabular}{llr}
\hline \multicolumn{3}{c}{ One-Sample Kolmogorov-Smirnov Test } \\
\hline & & \multicolumn{1}{c}{$\begin{array}{c}\text { Unstandardized } \\
\text { Residual }\end{array}$} \\
\hline $\mathrm{N}$ & Mean & 104 \\
\cline { 2 - 3 } & Std. Deviation & .0000000 \\
\hline Normal Parameters ${ }^{\mathrm{a}}$ & Absolute & .3 .39211693 \\
\cline { 2 - 3 } & Positive & .046 \\
\cline { 2 - 3 } & Negative & -.032 \\
\hline Kolmogorov-Smirnov Z & & .465 \\
\hline Asymp. Sig. (2-tailed) & & .982 \\
\cline { 2 - 3 }
\end{tabular}

a. Test distribution is Normal.

Sumber: Data primer diolah, Tahun 2019

Dari data pada table 6 yang telah diperoleh dari program SPSS, maka dapat diketahui bahwa nilai Asymp.sig (2-tailed) dalam penelitian ini adalah sebesar 0,982 lebih besar dari < 0,05, maka dapat diambil kesimpulan bahwa data dalam penelitian ini berdistribusi secara normal.

\section{Uji Multikolinearitas}

Uji Multikolinearitas digunakan untuk melihat apakah ditemukan adanya korelasi antar variabel independen. Uji multikolinearitas dalam penelitian ini Menggunakan Software Program SPSS versi 23. Jika terjadi adanya korelasi antar variabel maka ditemukan adanya gelaja multikolinearitas. Model regresi berganda yang baik dapat dijalankan jika tidak adanya gejala multikolinearitas antar variabel. Data uji multikolinearitas dalam penelitian ini dapat dilihat pada tabel 7 sebagai berikut:

Tabel 7

Hasil Uji Multikolinearitas

\begin{tabular}{|c|c|c|c|c|c|c|c|}
\hline \multirow[b]{3}{*}{ Model } & \multicolumn{3}{|c|}{ Coefficients $^{a}$} & \multirow[b]{3}{*}{$\mathrm{t}$} & \multirow[b]{3}{*}{ Sig. } & \multirow{2}{*}{\multicolumn{2}{|c|}{$\begin{array}{l}\text { Collinearity } \\
\text { Statistics }\end{array}$}} \\
\hline & \multicolumn{2}{|c|}{$\begin{array}{l}\text { Unstandardized } \\
\text { Coefficients }\end{array}$} & \multirow{2}{*}{$\begin{array}{c}\begin{array}{c}\text { Standardized } \\
\text { Coefficients }\end{array} \\
\text { Beta } \\
\end{array}$} & & & & \\
\hline & $\mathrm{B}$ & Std. Error & & & & Tolerance & VIF \\
\hline 1 (Constant) & 5.809 & 4.266 & & 1.362 & .176 & & \\
\hline Sikap & .436 & .295 & & .1161 .477 & .143 & .926 & 1.080 \\
\hline Personal Cost Of Reporting & .548 & .085 & & .5236 .407 & .000 & .855 & 1.169 \\
\hline $\begin{array}{l}\text { Tingkat Keseriusan } \\
\text { Kecurangan }\end{array}$ & .240 & .105 & & .1882 .280 & .025 & .836 & 1.196 \\
\hline
\end{tabular}

Sumber: Data primer diolah, Tahun 2019 
Dari data pada tabel 4.17 diatas, dapat diketahui bahwa variabel independen sikap memiliki nilai tolerance 0,926 atau lebih besar > dari 0,10, maka dapat diambil kesimpulan bahwa tidak terjadi gejala multikolinearitas pada variabel sikap, maupun variabel personal cost of reporting dan tingkat keseriusan kecurangan. Dengan nilai VIF 0,855 >0,10 dan 0,836 > 0,10.

\section{Uji Heterokedastisitas}

Uji heterokedastisitas dalam penelitian ini dilakukan dengan menggunakan Software SPSS Versi 23. Uji heterokedastisitas digunakan untuk melihat apakah model regresi apakah terjadi ketidaksamaan variabel dari satu pengamatan ke pengamatan lainnya. Uji heterokedastisitas dapat menggunakan metode Uji glejser. Syarat pengambilan keputusan dalam uji heterokedastisitas adalah jika nilai sig lebih besar > dari pada 0,05 sebaliknya apabila nilai sig lebih kecil < dari pada 0,05 maka dapat dikatakan data dalam penelitian mengalami gejala heterokedastisitas. Uji heterokedastisitas dalam penelitian ini pada tabel 8 sebagai berikut :

\section{Tabel 8}

Hasil Uji Heterokedastisitas Coefficients $^{\mathrm{a}}$

\begin{tabular}{|c|c|c|c|c|c|}
\hline \multirow[b]{3}{*}{ Model } & \multicolumn{3}{|c|}{ Coefficients $^{a}$} & \multirow[b]{3}{*}{$\mathrm{t}$} & \multirow[b]{3}{*}{ Sig. } \\
\hline & \multicolumn{3}{|c|}{ Unstandardized Coefficients Standardized Coefficients } & & \\
\hline & $\mathrm{B}$ & Std. Error & Beta & & \\
\hline 1 (Constant) & 2.524 & 2.544 & & \multicolumn{2}{|c|}{.992 .324} \\
\hline Sikap & .080 & .176 & .047 & \multicolumn{2}{|c|}{.452 .652} \\
\hline Personal Cost Of Reporting & .021 & .051 & .045 & \multicolumn{2}{|c|}{.419 .676} \\
\hline Tingkat Keseriusan Kecurangan & -.071 & .063 & \multicolumn{3}{|c|}{$-.123-1.135 .259$} \\
\hline a. Dependent Variable: RES2 & & & & & \\
\hline
\end{tabular}

Sumber: Data primer diolah, Tahun 2019

Dari data pada tabel 8 diatas maka dapat diambil kesimpulan bahwa variabel sikap (X1) diperoleh nilai sig sebesar 0,652 hal ini menunjukkan bahwa variabel sikap tidak terjadi gejala heterokedastisitas, dikarenakan nilai sig yang diperoleh lebih besar > dari pada 0,05. Sedangkan untuk variabel personal cost of reporting dan tingkat keseriusan kecurangan juga tidak terjadi gejala heterokedastisitas dengan nilai sig masing-masing 0,676>0,05 dan 0,259>0,05.

\section{Analisis Data}

Berdasarkan dari data kuesioner yang telah disebar serta dikumpulkan, maka akan dilakukan analisis data untuk mendapatkan hasil dari penelitian. Teknik analisis data dalam penelitian ini akan menggunakan regresi berganda. Hasil dari analisis data regresi berganda dapat dijelaskan pada tabel 9 sebagai berikut: 
Tabel 9

Hasil Uji Koefisien Regresi Berganda

\begin{tabular}{|c|c|c|c|c|c|c|}
\hline \multicolumn{7}{|c|}{ Coefficients $^{a}$} \\
\hline \multirow[b]{2}{*}{ Model } & \multicolumn{4}{|c|}{ Unstandardized Coefficients Standardized Coefficients } & \multirow[b]{2}{*}{$\mathrm{t}$} & \multirow[b]{2}{*}{ Sig. } \\
\hline & B & Std. Error & Beta & & & \\
\hline 1 (Constant) & 5.809 & 4.266 & & & 1.362 & .176 \\
\hline Sikap & .436 & 295 & & 116 & 1.477 & 143 \\
\hline Personal Cost Of Reporting & .548 & .085 & & .523 & 6.407 & .000 \\
\hline Tingkat Keseriusan Kecurangan & .240 & 105 & & 188 & 2.280 & .025 \\
\hline
\end{tabular}

a. Dependent Variable: Intention Whistleblowing

Sumber: Data primer diolah, Tahun 2019

\section{Uji F (Simultan)}

Uji F dilakukan untuk melihat pengaruh secara bersama-sama antara variabel independen dengan variabel dependen. Kriteria pengambilan keputusan dalam Uji F menurut ghozali (2007) adalah sebagai berikut: Jika nilai nilai signifikansi lebih kecil < daripada 0,05 maka dapat dikatakan Ha diterima, dengan kata lain, seluruh variabel independen secara bersama-sama berpengaruh signifikan terhadap variabel dependen.

Uji $F$ juga dapat dilakukan dengan membandingkan antara $F_{\text {hitung }}$ dengan $F_{\text {tabel. }}$ Dimana jika $F_{\text {hitung }}>F_{\text {tabel }}$ maka terdapat pengaruh secara bersama-sama antara variabel independen dengan variabel dependen. Sebaliknya apabila nilai $F_{\text {hitung }}<F_{\text {tabel }}$ maka dapat disimpulkan tidak terdapat pengaruh secara bersama-sama antara variabel independen dengan variabel dependen.Uji F dalam penelitian ini dapat dilihat pada tabel 4.20 sebagai berikut :

Tabel 10

Hasil Uji F (F-test) Simultan

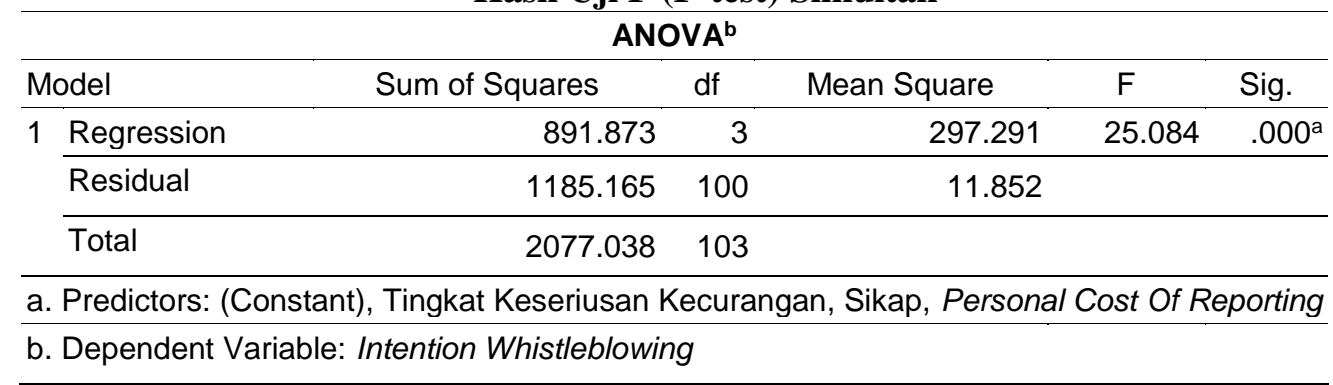

\section{Sumber: Data primer diolah, Tahun 2019}

Dari data pada tabel 4.20 dapat diambil kesimpulan bahwa nilai signifikansi untuk pengaruh variabel $\mathrm{X}_{1}, \mathrm{X}_{2}$ dan $\mathrm{X}_{3}$ secara silmutan atau bersama-sama terhadap $\mathrm{Y}$ adalah sebesar $0,000<0,05$ dan nilai $F_{\text {hitung }} 25,084>F_{\text {tabel }}$ 2,69 sehingga dapat disimpulkan bahwa terdapat pengaruh $\mathrm{X}_{1}, \mathrm{X}_{2}$, dan $\mathrm{X}_{3}$ secara simultan terhadap $\mathrm{Y}$. Hal ini mengindikasikan bahwa secara bersama-sama ketiga variabel independen mempengaruhi secara langsung terhadap variabel dependen.

\section{Uji Koefisien Determinasi ( $R^{2}$ Square $)$}

Uji koefiesien determinasi digunakan untuk mengetahui kontribusi variabel bebas terhadap variabel terikat dengan melihat dari nilai Adjusted $R$ Square, dikarenakan penelitian ini 
menggunakan analisis regresi berganda dengan menggunakan variabel lebih dari satu variabel. Adjusted $R^{2}$ berarti $R^{2}$ sudah disesuaikan dengan derajat bebas dari masing-masing jumlah kuadrat yang tercakup didalam perhitungan Adjusted $R^{2}$. Nilai dari koefisien determinasi dalam penelitian ini dapat dilihat pada tabel 4.21 sebagai berikut :

Tabel 11

Hasil Uji Koefisien Determinasi $\left(\mathbf{R}^{2}\right)$

\begin{tabular}{|c|c|c|c|c|}
\hline \multicolumn{5}{|c|}{ Model Summary } \\
\hline Model & $\mathrm{R}$ & R Square & $\begin{array}{l}\text { Adjusted R } \\
\text { Square }\end{array}$ & $\begin{array}{l}\text { Std. Error of the } \\
\text { Estimate }\end{array}$ \\
\hline 1 & $.655^{\mathrm{a}}$ & .429 & .412 & 3.443 \\
\hline
\end{tabular}

Berdasarkan hasil olah data pada tabel 4.21 diatas, diketahui nilai Adjusted $R^{2}$ adalah sebesar 0,412. Hal ini mengindikasikan bahwa kontribusi variabel independen yakni pengaruh sikap, personal cost of reporting dan tingkat kecurangan terhadap variabel dependen adalah sebesar $41,20 \%$. Sedangkan $58,80 \%$ lainnya ditentukan oleh faktor lain di luar model yang tidak terdeteksi dalam penelitian ini.

\section{Uji Hipotesis (T-test)}

Uji hipotesis digunakan untuk mengetahui secara masing-masing pengaruh dari variabel independen terhadap variabel dependen. Uji hipotesis dapat dilakukan dengan melihat hasil dari olah data secara SPSS. Apabila nilai sig lebih kecil < daripada 0,05 atau nilai $t_{\text {hitung }}>t_{\text {tabel }}$ maka dapat dikatakan terdapat pengaruh variabel $\mathrm{X}$ terhadap variabel Y. Sebaliknya apabila nilai sig lebih besar $>$ daripada 0,05 atau nilai $t_{\text {hitung }}<t_{\text {tabel }}$ maka dapat dikatakan tidak terdapat pengaruh antara variabel $\mathrm{X}$ terhadap variabel $\mathrm{Y}$. Uji t dalam penelitian ini dapat dijabarkan sebagai berikut:

\section{Pengujian Hipotesis 1 (Satu)}

Pengujian hipotesis ini dilakukan untuk membuktikan pengaruh sikap terhadap intention whistleblowing yang dilakukan dengan pengujian data secara statistik. Data dapat ditampilkan pada tabel 12 sebagai berikut :

Tabel 12

Hasil Uji Hipotesis (t-test) pertama (Hipotesis 1) Coefficients $^{\mathbf{a}}$

\begin{tabular}{|c|c|c|c|c|c|c|}
\hline \multicolumn{7}{|c|}{ Coefficients $^{a}$} \\
\hline \multirow[b]{2}{*}{ Model } & \multicolumn{2}{|c|}{ Unstandardized Coefficients } & \multicolumn{2}{|c|}{ Standardized Coefficients } & \multirow[b]{2}{*}{$\mathrm{t}$} & \multirow[b]{2}{*}{ Sig. } \\
\hline & $B$ & Std. Error & Beta & & & \\
\hline 1 (Constant) & 5.809 & 4.266 & & & 1.362 & .176 \\
\hline Sikap & .436 & .29 & & .116 & 1.477 & .143 \\
\hline
\end{tabular}

a. Dependent Variable: Intention Whistleblowing

Sumber: Data primer diolah, Tahun 2019 
Dari data pada tabel 4.22 diatas dapat disimpulkan pengaruh $\mathrm{X}_{1}$ terhadap $\mathrm{Y}$ adalah sebesar $0,143>0,05$ dan nilai thitung $1,477<t_{\text {tabel }} 1,983$ dengan koefisien regresi $(\beta)$ bernilai positif 0,436. Sehingga dapat diambil kesimpulan bahwa variabel sikap tidak berpengaruh signifikan terhadap intention whistleblowing atau dapat diambil kesimpulan bahwa tidak ada pengaruh antara $\mathrm{X}_{1}$ sikap dengan variabel $\mathrm{Y}$ intention whistleblowing maka dapat dikatakan Hipotesis H1 Ditolak.

\section{Pengujian Hipotesis 2 (dua)}

Pengujian hipotesis ini dilakukan untuk mengetahui pengaruh personal cost of reporting terhadap intention whistleblowing yang dilakukan dengan pengujian data secara statistik melalui program SPSS. Data hasil uji t-test dalam penelitian ini dapat dilihat pada tabel 13 sebagai berikut :

Tabel 13

Hasil Uji Hipotesis (t-test) kedua (Hipotesis 2)

\begin{tabular}{|c|c|c|c|c|c|}
\hline \multicolumn{6}{|c|}{ Coefficients $^{a}$} \\
\hline \multirow[b]{2}{*}{ Model } & \multicolumn{2}{|c|}{$\begin{array}{l}\text { Unstandardized } \\
\text { Coefficients }\end{array}$} & \multirow{2}{*}{$\begin{array}{c}\begin{array}{c}\text { Standardized } \\
\text { Coefficients }\end{array} \\
\text { Beta } \\
\end{array}$} & \multirow[b]{2}{*}{$\mathrm{t}$} & \multirow[b]{2}{*}{ Sig. } \\
\hline & $\mathrm{B}$ & Std. Error & & & \\
\hline 1 (Constant) & 5.809 & 4.266 & & 1.362 & .176 \\
\hline $\begin{array}{l}\text { Personal Cost Of } \\
\text { Reporting }\end{array}$ & .548 & .085 & & .5236 .407 & .000 \\
\hline
\end{tabular}

Sumber: Data primer diolah, Tahun 2019

Pengujian hipotesis dilakukan dengan membandingkan $t_{\text {hitung }}$ dengan nilai $t_{\text {tabel. }}$. Hipotesis diterima jika nilai $t_{\text {hitung }}>t_{\text {tabel }}$ atau nilai sig $<0,05$. Dari data pada tabel 4.23 diatas, diketahui nilai $t_{\text {tabel }}$ pada $\mathrm{sig}=0.05$ adalah 1,983 . Variabel personal cost of reporting diketahui nilai $t_{\text {hitung }}$ adalah sebesar 6,407 dan nilai sig adalah $=0,002$. Dengan demikian dapat dikatakan bahwa nilai $\mathrm{t}_{\text {hitung }}>\mathrm{t}_{\text {tabel }} 6,407>1,983$ atau nilai signifikansi $0,002<0,05$. Nilai koefisien beta $(\beta)$ dari variabel personal cost of reporting bernilai positif 0,548 .

Hal ini menunjukkan bahwa penelitian ini membuktikan personal cost of reporting berpengaruh positif signifikan terhadap intention whistleblowing. Dengan demikian hipotesis kedua $\left(\mathrm{H}_{2}\right)$ dalam penelitian ini Ditolak. Hal ini dikarenakan nilai koefisien beta $(\beta)$ berpengaruh positif sebab didalam hipotesis penelitian peneliti menduga bahwa pengaruh personal cost of reporting terhadap intention whistleblowing berpengaruh negatif. Namun dari hasil penelitian ditemukan arah pengaruh dari personal cost of reporting ke arah positif, maka dari itu hipotesis penelitian ditolak.

\section{Pengujian Hipotesis 3 (tiga)}

Pengujian hipotesis ini dilakukan untuk mengetahui pengaruh tingkat keseriusan kecurangan terhadap intention whistleblowing yang dilakukan dengan melakukan pengujian data statistik menggunakan program SPSS. Data hasil uji hipotesis ( $t$-test) dalam penelitian ini dapat dilihat pada tabel 14 sebagai berikut : 


\section{Tabel 14}

\begin{tabular}{|c|c|c|c|c|c|}
\hline \multicolumn{6}{|c|}{ Hasil Uji Hipotesis (t-test) Ketiga (Hipotesis 3) } \\
\hline \multicolumn{6}{|c|}{ Coefficients $^{\mathrm{a}}$} \\
\hline \multicolumn{6}{|c|}{ Unstandardized Coefficients Standardized Coefficients } \\
\hline Model & $\mathrm{B}$ & Std. Error & Beta & $\mathrm{t}$ & Sig. \\
\hline 1 (Constant) & 5.809 & 4.266 & & 1.362 & 176 \\
\hline Tingkat Keseriusan Kecurangan & 240 & .105 & & 1882.280 & .025 \\
\hline
\end{tabular}

Sumber: Data primer diolah, Tahun 2019

Dari data pada tabel 4.24 diatas dapat diambil kesimpulan bahwa nilai sig pengaruh variabel $\mathrm{X}_{3}$ terhadap variabel $\mathrm{Y}$ adalah sebesar $0,02<0,05$ dan nilai thitung 2,280 $>t_{\text {tabel }} 1,983$ dengan koefisien regresi $(\beta)$ bernilai positif 0,240 . Sehingga dapat diambil kesimpulan bahwa terdapat pengaruh signifikan positif antara variabel tingkat keseriusan kecurangan dengan intention whistleblowing. Maka dapat diartikan bahwa terdapat pengaruh antara variabel $\mathrm{X}_{3}$ Tingkat keseriusan kecurangan terhadap variable (Y) Intention Whistleblowing Sehingga dapat diambil kesimpulan bahwa Hipotesis $\mathbf{H}_{3}$ Diterima. Hal ini juga mengindikasikan bahwa tingkat keseriusan kecurangan mempunyai pengaruh signifikan terhadap intention whistleblowing, dengan arah pengaruh positif

\section{PEMBAHASAN}

\section{Pengaruh Sikap terhadap Intention Whistleblowing}

Penelitian Maulana ilham saud (2016) dengan tiga item pernyataan. Dari hasil penelitian diperoleh bahwa nilai sig sebesar $0,152>$ dari 0,05, maka dapat diambil kesimpulan bahwa hipotesis $\mathrm{H}_{1}$ ditolak. Hal ini tidak sejalan dengan penelitian sebelumnya yang dilakukan oleh Salsabila (2018), Damayanthi et al. (2017), Siallagan et al. (2017) dan Bagustianto \& Nurkholis (2013) yang menyatakan bahwa sikap berpengaruh signifikan terhadap intention whistleblowing. Namun, hasil penelitian ini sejalan dengan penelitian yang dilakukan oleh Muhammad saud (2016), Park \& Blenkinsopp (2009), Siti Aliyah (2015) dan Purwantini (2016) yang menyatakan bahwa sikap tidak berpengaruh terhadap intention whistleblowing.

Bentuk sikap dari Aparatur Sipil Negara yang lebih memilih mengundurkan diri tersebut, berbanding lurus dengan penelitian yang telah dilakukan oleh peneliti terhadap variabel Sikap. Dimana Sikap tidak berpengaruh positif terhadap intention whistleblowing. Aparatur Sipil Negara menganggap bahwa pengaduan pelanggaran tidak akan menghentikan kecurangan dalam organisasi. Dengan pengunduran diri tersebut terlihat sikap dari Aparatur Sipil Negara lebih memilih untuk menutup mata atas kasus pelanggaran yang terjadi, padahal mereka bisa melaporkan tindakan kecurangan dengan dipayungi atau dapat dilindungi oleh Peraturan Bupati Nomor 16 Tahun 2018 tentang Pedoman Penyampaian Pengaduan Oleh Aparatur Sipil Negara Dan/Atau Pejabat Lain (Whistleblower System) di lingkungan Pemerintah Kabupaten Padang Pariaman.

\section{Pengaruh Personal Cost Of Reporting Terhadap Intention Whistleblowing}

Hasil dari penelitian ini menunjukkan bahwa personal cost of reporting berpengaruh secara positif terhadap intention whistleblowing dengan nilai sig sebesar $0,000<0,05$ dan thitung $6,407>t_{\text {tabel }} 1,983$. Penelitian ini tidak sejalan dengan penelitian yang dilakukan oleh Alleyne (2012) dan penelitian Hanif (2017) yang menyatakan bahwa sanksi yang akan diberikan dan 
dihadapi dari seorang whistleblower ketika melakukan whistleblowing dapat menjadi salah satu pertimbangan utama bagi pelapor untuk melakukan whistleblowing.

Penelitian ini sejalan dengan penelitian yang dilakukan oleh sabang (2013), winardi (2013), dan nurkholis (2015) yang menyatakan terdapat pengaruh antara variabel personal cost of reporting terhadap intention whistleblowing. Meskipun adanya ancaman atas tindakan pelaporan kecurangan tetap tidak akan menurunkan minat dari whistleblower untuk menjadi seorang whistleblowing. Terdapat justifikasi dalam penelitian ini. Dimana seorang Aparatur Sipil Negara pada Pemerintah Daerah Kab. Padang Pariaman tidak takut akan kehilangan jabatan yang di amanahkan. Itu terlihat dari adanya pengunduran diri atas beberapa jabatan di Badan Pengelola Keuangan Daerah. Justifikasi lainnya yang dapat diberikan dalam penelitian ini adalah, banyak dari para pegawai merasa akan terancam jabatan yang telah diamanhakan jika mengungkapkan kecurangan. Sebab masih banyak dari pegawai yang merasa bahwa kenaikan pangkat dan jabatan adalah segalanya.

\section{Pengaruh Tingkat Keseriusan Kecurangan Terhadap Intention Whistleblowing}

Tingkat keseriusan kecurangan merupakan salah satu faktor yang dapat dijadikan penentu untuk melihat kaitan ataupun hubungan antara variabel independen dengan variabel dependen. Hasil pengujian dari hipotesis dalam penelitian ini menunjukkan bahwa nilai sig 0,02>0,05 serta nilai $\mathrm{t}_{\text {hitung }} 2,280<\mathrm{t}_{\text {tabel }}$ 1,983 maka dapat diambil kesimpulan bahwa hipotesis $\mathrm{H}_{3}$ Diterima.

Hasil dari penelitian ini juga membuktikan konsep materialitas tingkat keseriusan kecurangan dan sejalan dengan penelitian sebelumnya yang dilakukan oleh Menk (2011) dan Bagustianto (2014). Hasil dari penelitian ini juga sejalan dengan penelitian sebelumnya yang dilakukan oleh Raharjo (2015) dimana jika seseorang melakukan pelanggaran besar atau dapat dianggap sebagai pelanggaran serius, maka akan semakin besar juga niat yang dilakukan anggota organisasi untuk melaporkan dugaan dari pelanggaran yang dilakukan tersebut.

\section{KESIMPULAN}

\section{Kesimpulan}

1. Tingkat capaian responden pada variabel sikap sangat tinggi serta dapat menggambarkan bahwa responden memahami dari setiap item pernyataan yang diberikan. Dari hasil penelitian untuk variabel sikap tidak berpengaruh terhadap intention whistleblowing. Tingkat capaian responden pada variabel personal cost of reporting juga dapat menggambarkan dari pemahaman responden mengenai kuesioner yang diberikan. Dari hasil penelitian untuk variabel personal cost of reporting berpengaruh positif terhadap intention whistleblowing.

2. Tingkat capaian responden pada variabel tingkat keseriusan kecurangan juga menggambarkan bahwa responden memahami setiap pernyataan yang diberikan dari kuesioner yang telah dibagikan. Dari hasil penelitian untuk variabel tingkat keseriusan kecurangan tidak berpengaruh terhadap intention whistleblowing.

3. Variabel tingkat keseriusan kecurangan terbukti berpengaruh terhadap intention whistleblowing, hal ini juga mengindikasikan bahwa tingkat keseriusan kecurangan yang dapat merugikan organisasi akan semakin membuat seseorang ingin secepatnya mengungkapkan kecurangan yang telah dilakukan. 


\section{Saran}

1. Diharapkan penelitian selanjutnya dapat menambah jumlah sampel yang digunakan dalam penelitian untuk dapat lebih menggambarkan secara keseluruhan mengenai pemahaman terhadap intention whistleblowing.

2. Penelitian selanjutnya diharapkan dapat menggunakan variabel lain yang belum ada dalam penelitian ini yang juga dapat mempengaruhi intention whistleblowing, serta dapat menggunakan indikator lain dalam pengukuran yang digunakan dalam penelitian. Penelitian selanjutnya juga dapat menggunakan teknik analisis yang berbeda seperti menggunakan teknik wawancara untuk dapat melihat pengaruh dari intention whistleblowing.

\section{DAFTAR PUSTAKA}

Afuan, Putra Fajrian. Pengaruh Faktor Individual dan Faktor Situasional terhadap Niat Melakukan Whistleblowing. Tesis, Fakultas Ekonomi, Universitas Gajah Mada Yogyakarta, 2015

Agung, S. M. (2011). Perlakuan Terhadap Pelapor Tindak Pidana (Whistle Blower) dan Saksi Pelaku Yang Bekerjasama (Justice Collaborator) di dalam Perkara Tindak Pidana Tertentu.

Ahmad, S.A., M. Smith, and Z. Ismail. 2013. Internal Whistleblowing Intentions by Internal Auditors: A Prosocial Behaviour Perspective. Malaysian Accounting Review, 12 (1), 145181

Ajzen, I. (1991). The theory of planned behavior. Organizational Behavior and Human Decision Processes, 50(2), 179-211. https://doi.org/10.1016/0749-5978(91)90020-T

Alleyne,P.,D.Devonish, J.Allmandan Ayanna Young.2010. "Measuring Ethical Perceptions and Intentions Among Undergraduate Student in Barbados". The Journal of American Academy of Business, Cambrige, Vol.15, No.2: 319 -326

Alleyne, P., Hudaib, M. and Pike, R., 2013. "TowardsA Conceptual Model of Whistle-Blowing Intentions Among External Auditors".The British Accounting Review, 45 (1),10.

Aliyah, S. (2015). Analisis Faktor-faktor yang Mempengaruhi Minat Pegawai Melakukan Tindakan Whistleblowing. Jurnal Dinamika Ekonomi \& Bisnis, 12(2), 173-189.

Anggraeny, A. N. (2018). Pengaruh Lingkungan Etika, Sifat Machiavellian dan Personal Cost Terhadap Niat untuk Melakukan Whistleblowing. III, 224-234.

Bagustianto,Rizki., dan Nurkholis. 2013. "Faktor-Faktor yang Mempengaruhi Minat Pegawai Negeri Sipil (PNS) untuk melakukan Whistleblowing(Studi pada PNS BPK RI)".

Baron, R. A., \& Branscombe, N. R. (2012). Social psychology 13th ed. New Jersey:Pearson Education, Inc.

Cheisviyanny, C., \& Arza, F. I. (2019, April). Whistleblowing Intention of Internal Governmental Auditors In Padang. In 2nd Padang International Conference on Education, Economics, Business and Accounting (PICEEBA-2 2018). Atlantis Press.

Damayanthi, Kadek Shintya Rahayu Dewi., EdySujana, dan Nyoman TrisnaHerawati. 2017. "Pengaruh Norma Subjektif, Sikap pada Perilaku, Persepsi Kontrol Perilaku terhadap Niat melakukan Pengungkapan Kecurangan (Whistleblowing) (Studi empiris pada Mahasiswa Akuntansi Program S1 dan D3 Universitas Pendidikan Ganesha)". E-jurnalS1 Akuntansi Universitas Pendidikan Ganesha, Vol.8,No.2. 
Detiknews. (2013). Drama Susno Duadji, dari l'Cicak vs Buayal' Hingga Jadi Buron Kejagung. Retrieved from https://news.detik.com/berita/2232741/drama-susno-duadji-dari-cicak-vsbuaya-hingga-jadi-buron-kejagung?nd772204btr=

Eisenberger, Robert., dan RobinHuntington. 1986. "Perceived Organizational Support”. Journal of Applied Psychology, Vo.71,No.3:500-507

Hanif, Rheny Afriana., dan FajarOdiatma. 2017. "Pengaruh Personal Cost Reporting, Status Wrong Doer dan Tingkat Keseriusan Kesalahan terhadapWhistleblowing Intention". Jurnal Politeknik Celtex Riau,Vol.10,No.1:11-20.

HUMAIRA, N. (2017). Pengaruh Faktor Individual Dan Negeri Sipil Untuk Melakukan Tindakan Whistle-Blowing Internal.

https://covesia.com/archipelago/baca/83928/tiga-pejabat-dppkad-pemkab-padang-pariamanmengundurkan-diri-dalam-waktu-berdekatan.

Komite Nasional Kebijakan Governance. (2008). Pedoman Sistem Pelaporan Pelanggaran SPP (Whistleblowing System - WBS).

Marliza, R. (2018). Pengaruh Personal Cost of Reporting komitmen organisasi dan tingkat keseriusan kecurangan terhadap niat melakukan whistleblowing. Ejournal.Unp.Ac.Id, 43.

Maulana Saud, I. (2017). Pengaruh Sikap dan Persepsi Kontrol Perilaku Terhadap Niat Whistleblowing Internal-Eksternal dengan Persepsi Dukungan Organisasi Sebagai Variabel Pemoderasi. Jurnal Akuntansi Dan Investasi, 17(2), 209-219. https://doi.org/10.18196/jai.2016.0056.209-219

Nurkholis, R. B. (2015). Faktor-faktor yang mempengaruhi minat pegawai negeri sipil (PNS) untuk melakukan tindakan whistleblowing (Studi pada PNS BPK RI). Jurnal Ekonomi Dan Keuangan, 19(2), 276-295.

Park, H. and Blenkinsopp, J., 2009. "WhistleblowingAs Planned Behavior - A Survey OfSouth Korean Police Officers". Journal ofBusiness Ethics, 85 (4), 545-556

Pariaman, P. D. P. (2016). PERATURAN DAERAH.

Purwantini, Anissa Hakim.2016."Pengaruh Komitmen Profesional, Pertimbangan Etis, dan Komponen PerilakuTerencana terhadap Intensi Whistleblowing Internal”. Jurnal Ekonomi Syariah,Vol.4, No.1: 142-159.

Raharjo, Ferri Dwi dan Praktisi Krakatau Steel. (2015). Faktor Yang Mempengaruhi Pelaporan Whistleblowing Internal dengan Tingkat Pendidikan sebagai Variabel Moderasi Persepsi

Karyawan di PT.Krakatau Steel. Media Riset Akuntansi, Auditing \& Informasi, Vol 15 No.2.

Rodiyah, S. (2015). Pengaruh Sifat Machiavellian, Lingkungan Etika dan Personal Cost Terhadap Intensi Melakukan Whistleblowing. 3(2), 54-67.

Schultz, J. J., et al., 1993. "An Investigation ofThe Reporting of Questionable Acts in AnInternational Setting”. Journal of AccountingResearch, 31, 75-103.

Setyawati, I., Ardiyani, K., \& Ragil Sutrisno, C. (2015). Faktor-Faktor Yang Mempengaruhi Niat Untuk Melakukan Whistleblowing Internal. Jurnal Ekonomi Dan Bisnis, 17(2), 22-33.

Salsabila, Syf. 2018. "Faktor-Faktor yang Mempengaruhi Niat dan Perilaku Whistleblowing Mahasiswa Akuntansi". Jurnal Kajian Ilmiah Akuntansi Fakultas Ekonomi UNTAN (KIAFE), Vol.7,No.1:1-21

Saud, Maulana Ilham. 2016. "Pengaruh Sikap dan Persepsi Kontrol Perilaku terhadap Niat Whistleblowing Eksternal -Internal dengan Persepsi Dukungan Organisasi sebagai variabel Moderasi”. Jurnal Akuntansi dan Investasi, Vol.17, No.2:209-219. 
Siallagan, H., A.Rohman, dan MuhammadDin. 2017. "The Effect of Professional Commitment, Attitude, Subjektif Norms and Perceived Behavior Control on Whistleblowing Intention". International Journal of Civil and Technology,8(8) :508-5

SindoNews.com. (2014). Pimpinan DPRD Padang Pariaman jadi tersangka. Retrieved from https://daerah.sindonews.com/read/857550/24/pimpinan-dprd-padang-pariaman-jaditersangka-1398397667

Winardi, Rijadh Djatu. 2013. "The Influence of Individual and Situational Factors on LowerLevel Civil Servants' Whistle-Blowing Intention in Indonesia”. Journal of Indonesian Economy and Business, Vol.28, No.3: 361-376

Zakarija Achmat. (2015). Theory of Planned Behavior Masihkah Rele. Academiaedu, 1-26. Retrieved from https://www.academia.edu/6121811/Theory_Of_Planned_Behavior 